\title{
Rethinking Two Scientific Currents, Westernism and Philosophical Orientation, in Iran of the Islamic Republic Era
}

\author{
Aref Barkhordari ${ }^{1, *}$ \\ ${ }^{1}$ Department of Political Thought, University of Tehran, Tehran, Iran \\ *Correspondence: Department of Political Thought, University of Tehran, 16 Azar St- \\ Enghelab St- Enghelab Square -Mailbox: 6619-14155 Tehran, Iran. Tel: 98-913-979-1522 \\ E-mail: arefbarkhordari@ut.ac.ir
}

Received: May 9, 2020 Accepted: June 15, 2020 Published: July 16, 2020

doi:10.5296/jsr.v11i2.17008ＵRL: https://doi.org/10.5296/jsr.v11i2.17008

\begin{abstract}
The present article, with emphasis on the descriptive-analytic method, is a description of the thoughts of the scholars of the two scientific, westernist and the Philosophy oriented currents، In Iran after the 1979 revolution. The Iranian revolution in the space of modernity as a paradigm dominating the world occred in 1979. During the revolution and afterwards many crises were created in the Iranian society and the new political system. In the wake of the crises, numerous religious and non-religious groups consisting of clerics, intellectuals and academics sought to eliminate them. Each of these groups proposed a solution to these crises according to their intellectual base and community space or various intellectual and philosophical tendencies. Some of these groups saw their solution in embracing scientificism and adherence to it, some embraced Western models, modernity, and harmony with the West, others saw the solution in following traditionalism and distance from the West and the rationality of the new world, And some have considered solutions to managing society based on the Islamic model. Following will explain the thoughts of the thinkers of the two major streams of thought from these currents.
\end{abstract}

Keywords: science, philosophy, reason, anti-west, modernity 


\section{Introduction}

Modernity is a phenomenon in which everything and everyone is revisited, i.e. the process of fundamental self and human independence. Modernity began when man decided to re-think everything and everyone, to criticize himself and his world. Since Descartes (1596-1650) stated his famous phrase (cogito) "I think therefore I am", modernity has emerged with the decline of scholastic thought, and its fundamental principles include mechanism and subjectivism (Bukhansky, 2000, P. 2).

Modernity is an epistemic and identity leap in the human being that created the change in one's view of the self and the world. After this epistemic and identity leap, the modern human felt the need to plan his world, take the world seriously, and exploit it more than ever before. Osborne regards modernity as a kind of modern quality and characteristic, a kind of modern experience that reflects the newness of the present as a break from the past. Modernity is associated with the idea of innovation, newness, creativity, pioneering, progress, development, taste, and fashion (Osborne, 1997, P. 346-355). Giddens views modernity as a new world built on three principles: (1) A special view of the world, a belief that man is the master and owner of the world, and along with this view, it brought new ideas such as freedom, equality, liberalism, rationalism, and humanism into the political culture. (2) Modernity is a set of economic entities such as free industrial and economic production. (3) It is a set of political institutions for nation-states (Jahanbegloo, 2005 a, p. 2-12). Jahanbegloo describes the modern era as a new society with the following characteristics: The individual is exalted and the tradition is criticized; the Descartes subject emerges and makes itself the owner of nature; the separation of religion and the state; the emphasis on individual liberties; Positive and critical view of the world; the emphasis on Galileo and Newtonian science; the era of instrumental reason; critical reason, and so on (Jahanbegloo, 2005 b, p. 71, 72 and 21).

Finally, what is referred to as modernity is a series of profound political, social, economic, intellectual, and cultural achievements in all spheres of personal and social life of humanity and it has elements such as secularism, individualism, rationalism, scientism, empiricism, humanism, rejection of tradition, freedom, equality, progress, and so on.

In the sphere of modernity as a paradigm dominating the world, numerous philosophical, political, social and economic discourses have formed. Some of these discourses have sought to deal with such situations, and some have sought to reconcile them. Iranian society was no exception and it was introduced to the modern world about 150 years ago (Barkhordari, 2020, p.58). The 1979 Iranian revolution also occurred in the modern world. Some believed that this revolution took place in opposition to modernity, while some considered it to be in compliance with modernity. However, in the sphere of modernity as the paradigm dominating the world, the 1979 revolution occurred in Iran and influenced its intellectual conditions by politicizing the atmosphere of Iranian society, and for some reason caused the growth of political and social thought and the formation of social and political discourses in the Iranian society.

The Iranian Revolution and its aftermath can be explored based on three issues: First, following the revolution, in addition to the political and cultural domination of the society, 
the clergy were able to assert their revolutionary ideology over the society and, on the other hand, cultivate political jurisprudence and present it as the dominant theory of governing the society. Secondly, after the revolution, many crises erupted in Iranian society: the Iran-Iraq war, the sharp decline in oil revenues, economic sanctions, economic mismanagement, rural migration to cities and war refugees, the growth in the population of those who demanded new cultural and social policies. On the other hand, the effects of globalization on Iranian culture, the desire for development and its outcomes, the issue of economic development and the development of modern technology, the question of democracy, freedom and its relation to religion and religious institutions were other factors that made the post-revolutionary conditions in Iran more complicated. These crises and the revolution itself raised many questions for theorists, such as whether Islamic jurisprudence is capable of responding to new social, economic, and scientific challenges; is technology, nationalism, and parliamentary democracy compatible with Islam? What can the Islamic Republic bring for the rest of the world? In addition, issues such as how to stop secularism and how to deal with the West and its various philosophical schools and so on. Third, Western philosophical approaches, especially the continental and analytic philosophies that were active in Iran before the revolution, also extended to Iran after the revolution and influenced the formation of various intellectual-philosophical, political, and social currents in the Iranian society.

These issues caused the formation of two trends: Firstly, they created various political, social, religious, and non-religious currents in the Iranian society, and secondly, each of these currents, influenced by their mentality, was in the pursuit of community management and accountability towards various issues. Non-religious movements were not very popular in the Iranian society, but their religious movements were divided into two groups: religious clergies and religious non-clergy thinkers. Among the religious non-clergy intellectual discourses, two influential discourses with religious and identity orientations are significant. One of them is the discourse of Abdolkarim Soroush who, with his religious affiliation, consciously seeks to reconcile religion with modernity and science, and to promote a scientific and rationalist perspective in Iran. Another discourse, whose intellectual origin goes back to Ahmad Fardid, is a discourse that has taken a religious and identity stance against subjectivity and the West, with its prominent figure being Reza Davari Ardakani. The arguments of these two discourses began with opposition at the beginning of the revolution and reached a climax, but with the transformations in the thoughts of these two thinkers, the two discourses have come close to each other. In the following, the ideas of these two thinkers will be considered with an emphasis on the concepts of scientism, westernism, and philosophy.

\section{Scientism, Westernism and Philosophical-Orientation in Iran after the Islamic Revolution}

\subsection{Soroush, Promoting Science and Choosing from the West}

Soroush grew up in Iran's political-religious structure, then studied pharmacy and went to England to study chemistry, but was drawn to the philosophy of science, analytical 
philosophy, and Popper's philosophy. He was influenced by both the Islamic-mystical thoughts and Western ideas. His main concern was the compatibility between religion and modernity. He sought to promote scientism and scientific approaches, to selectively utilize the achievements of the Western world in the Iranian society, and to solve the problems of society based on scientific views.

He put forward a methodological discussion on the nature of science and philosophy to defend science and to explain science based on Popper's system of thought. He divides science into two definitions: Science meaning knowledge, including all human knowledge regardless of its type (Soroush: 1997, p. 11). The other, science meaning knowledge based solely on direct experience (known as science) (ibid, p. 12). Soroush considers science to have the following characteristics:

(1) The method of science is experience and observation (ibid, p. 19).

(2) Experimental exploration is about the hypothesis or problem that one has in mind.

(3) Scientific interpretations are always made in the light of scientific theories and laws (ibid, p. 25). Scientific laws and theories must be capable of being experienced in order to be scientific and must be repeatable to be capable of being experienced (ibid, p. 26).

(4) Every scientific theory or law has three attributes:

A: It expresses a permanent order. B: it is capable of contingent prediction. C: it declares that the occurrence of some phenomena in the world is impossible and the more restrictive a law, the more scientific it becomes (ibid, p. 30).

When a law declares a possible phenomenon to be impossible, its meaning is that if the phenomena occur, the law will not be valid and all scientific laws act in this way, i.e. if some events occur, they will be invalidated. The laws are not compatible with everything and every condition and whatever happens makes no difference for them. The important attribute of scientific laws is their sensitivity to the world and this is what makes them falsifiable.

Falsifiability means not being compatible with all the possible phenomena and the law of falsifiability means a law for which we can see that the occurrence of a phenomenon will falsify it. In other words, anyone who has a legal claim must display in what circumstances he will abandon his claim (ibid, p. 31).

Influenced by Popper, Soroush believes that falsifiability does not mean that we are certain that these laws will be nullified and void; rather, even if the accuracy of a scientific law is guaranteed, it will still be falsifiable. Falsifiability is equal to being able to be experienced.

A law is scientific if it can be experienced, and it can be experienced when it is falsifiable, and it is falsifiable when it is not indifferent towards the outside world and its phenomena. When a claim is not falsifiable, it will not be able to predict anything. In addition, Soroush uses falsifiability equal to criticism. The claims that are non-falsifiable Criticizing and evaluating them through experience is also impossible، this makes them invulnerable. This invulnerability, whether good or bad, will certainly make the claim unscientific (ibid, p. 34). 
(5) The fifth characteristic of empirical knowledge is the selective nature of the scientific method. No science experiences and researches all aspects of a phenomenon.

About Philosophy, Soroush regards it as a type of science in its broad sense, i.e. knowledge, and he considers it different from experience and sense. Therefore, he places it in opposition to science in its particular or empirical sense, and believes: "Philosophy is a type of science in its broad meaning, it is a kind of consciousness of the world, but it differs from the consciousness that comes from sense and experience, and therefore philosophy stands in opposition to science as the empirical consciousness" (ibid, p. 43).

Soroush, influenced by the aforementioned methodological discourse which explains his scientific method, explores topics such as whether humanities is a science, selection from the West, theological issues, freedom and liberalism, human rights, and religious democratic governance in Iranian society.

\subsubsection{The Humanities are Scientific}

The reason for Soroush's focus on the humanities was the atmosphere of the Iranian Revolution and the opposition to it. His defense of modern sciences and humanities was in the period of opposition to modernity and Western ideas in Iran (Soroush, 1993, p. 2). Soroush, on the one hand, tried to show to the dissidents of the humanities that we should not have a holistic view of science, and on the other hand he tried to prove that although science do researches and information collection based on presuppositions (context of discovery), in the context of justification, it is intersubjective and objective, and therefore trustworthy.

Soroush provides the scientific-philosophical defense of the fields of sociology, education science, political science, economics, psychology and the like. He concludes that the human sciences, in the specific sense of the word, are science, claiming to embody that amount of human dignity and behavior that experience allows (ibid, p. 19).

Soroush, influenced by Popper, regards the method of social and human sciences the same as the method of natural sciences. He defends the humanities and considers the reasons for the skepticism about humanities in Iran to include: raw, conventional, and customary understandings, more rooted cultural reasons (ibid, p.7), such as the growth of mysticism, religious knowledge, and anthropology influenced by this culture and religion (ibid, p. 9).

Soroush considers humanities as a name that is given today to a discipline of human knowledge and considers a few constraints for it:

1. The human sciences are theoretical and generative, not consumer humanities.

2. Several scientific disciplines including sociology, education science, political science, economics and psychology are humanities. Philosophy, mysticism, ethics, and theology are not among them.

3. Humanities are mentally posited sciences. So law, ethics, language, and literature are also excluded from the humanities (ibid, p. 17).

In his view, if the humanities have one characteristic, they are empirical anthropology, and 
the same is exactly true of the natural sciences. In the definition of the human sciences, Soroush argues that "the human sciences are the sciences that regulate collective and individual, voluntary and involuntary, conscious and unconscious behaviors of humans in the form of empirical disciplines" (ibid, p. 24). Regularization in the Format of empirical disciplines is a characteristic that provides the scientific nature and objectivity of these sciences.

Soroush offers another definition of the humanities based on purpose and believes that the purpose of these sciences is to provide empirical predictions about human behavior. In the end, Soroush views science as a social construct that has an intersubjective state, which is the reason why he opposes the holism of the human sciences and the lack of knowledge of other human worlds (ibid, p. 58).

\subsubsection{The Theology of Soroush}

Soroush, influenced by the falsifiability and evolution of science, as well as using natural science for social sciences and humanities deals with theological issues. According to Popper, theories, including science, are developed through evolutionary stages, and scientific knowledge has an uncertain and speculative nature. No scientific theory can be called completely truthful and real (Bashirieh, 2000, p. 61-66). Affected by this concept, Soroush discusses the topics of the evolution of religious understanding, the expansion of the Shari'ah, the dynamic jurisprudence, the expansion of the experience of the Prophet and the minimal and maximal religion. He argues that "no written text expresses its meaning. The linguist's mind reads the meaning in the text. Similarly, the meaning of the phenomena of the world is not written on them, one has to know the language of the world to read and understand, science and philosophy teach this language to humans, and these languages are neither slow nor complete, but in constant evolution" (Soroush, 2003, p. 192). Therefore, Soroush believes that our understanding of the world is based on a historical understanding. Social and human institutions have a fluid existence rather than a fixed nature and accordingly he differentiates between religion and human knowledge. Soroush believes that sending religion is done by God and understanding it must be done by us, and this is where the religious knowledge that is purely related to human understanding comes into being. "We are dealing with religious knowledge everywhere that focuses on religion and is about religion, but it is not religion itself, and this is true for all human knowledge" (ibid, p. 53). Soroush considers religious knowledge in relation to other human knowledge after accepting the separation of religion from religious knowledge. He believes that "religious knowledge is a consumer knowledge which is directly influenced by the generative types of knowledge, and it should be said that firstly, there is no understanding of religion that does not rely on extrinsic knowledge and understanding. Secondly, if extrinsic understandings evolve, the religious understandings also evolve; and if they are stable, they will remain stable; and thirdly, extrinsic understandings are transformative" (ibid, p. 347).

Soroush considers the principle that any religious understanding relies on an external understanding as a falsifiable principle, namely that there is no instance of religious understanding in the book and tradition that does not require external thought to understand it, 
and finding such an instance does not lead to the nullification of this principle. According to the theory of the evolution and transformation of religious understanding, Soroush believes that this distinction between religion and religious understanding allows Muslims to reconcile between the eternal and the sacred on the one hand and the unholy and variable on the other, which results in a revival of Islam and harmony between Islam and the modern age. Later on, Soroush arrives at religious pluralism and believes that "our understanding of religious texts is necessarily diverse and multifaceted, and this diversity and plurality cannot be conveyed into a single understanding, and it is not only diverse and plural, but also fluid" (Soroush, 1998 , p. 2 and 4). Based on these same theoretical concepts, Soroush puts dynamic jurisprudence against traditional jurisprudence, and in his view, only dynamic jurisprudence can provide solutions to some practical issues raised when confronting modernity (Soroush, 2000 a, p. 51). Soroush claims that jurisprudence as a human science is interpretable and theoretical. Since science and philosophy are always evolving, understanding the religion must be the same. Soroush concluded that as philosophy and the natural sciences are always unfinished and in search of perfection, jurisprudential theory is also incomplete and transient.

\subsubsection{West According to Soroush}

Soroush provides two arguments regarding the west. One involves the westerners, their good and evil and their surroundings and behaviors, and the second is the existence and nature of the west. Influenced by Popper's historicism, he rejects the belief in the nature and holism of the West and the impossibility of choosing aspects of it. He introduces two types of westernism: a posteriori and a priori. A posteriori westernism means that we must first identify the land and history, customs, arts, science, philosophy, technology, and behavior of Western people from its good and bad, right and wrong, and then judge each one based on reason and thought (Soroush, 1993, p. 241) A priori westernism means we abandon precisions and research; We first give a general definition, and then we say the external west is realization of mental example, expansion of ultimate truth, and intellect of the general nature, and we should say by west we don't mean geographical east or west, this world or the hereafter; rather we mean a nature among all the defined natures. According to Soroush in a priori westernism, first they provide a definition of the west, and in this definition, west is the worst possible thing. In this definition, method, research, experience, and logic are considered the West's achievement and the product of subjectivity and the sign of loss of spirituality. Soroush sees this method as a Hegelian method in which they have taken on a few general concepts and have focused on their historical development and emergence (Barkhordari, 2019, p.13).

After examining the two westernism methods, Soroush considers west as a whole with a credit unity, not a real one, and considers the whole to be both degradable and feedable. In other words, he believes that the West does not have a spirit and nature transcending westerners and their conducts and behaviors to give them unity and identity; rather, the opposite is true, i.e. the West is nothing but conducts, behaviors, sciences, rituals, and apparent atheism and religiosity of the West (Soroush, 1993, p. 244).

Soroush believes west to consist of various elements and he argues for a type of selection 
from it (ibid, p. 237). Despite these arguments, Soroush accuses the westerners of hegemony and deception and believes that against the westerners, we should not bow down to worship them. Experience and nurture are the two great arts of intelligent westerners (ibid, p. 239).

\subsubsection{The Political Philosophy of Soroush}

Soroush's political philosophy includes the concepts of human rights, liberty, civil society, and religious democratic governance. Soroush, following Popper, modern-day rationalism, and liberal thinkers such as Locke, Rousseau, and Isaiah Berlin, accepts these concepts and strives to adapt them to Iranian society. In the discussion of freedom, Soroush examines freedom in the form of three headings: ceiling of freedom, just freedom, and freedom as a method. On the ceiling of freedom, he sees it as any other blessing that has both dimensions and restrictions. In discussing the ceiling of freedom, he has two views on freedom: the instrumental view and the right-based view. In the right-based view, he views freedom as a right which is fair and just and one of the achievements of the new world. In just freedom, Soroush regards freedom as part of justice and the only thing that restricts freedom is justice. In just freedom, influenced by Isaiah Berlin, he divides it into two types, i.e. positive and negative, or from and in. He sees freedom from [positive] as emancipation and freedom in [negative] being your own master (Soroush, 2000 b, p. 219). With regards to freedom as a method, Soroush sees freedom as a method for knowing, understanding, and learning (ibid, p. 219).

Human rights is another issue raised by Soroush. In this discussion, he is influenced by the rationalism of the modern age, the multiplicity of languages and the scientific system (Kuhn's discussion of the philosophy of science) (Soroush, 2001, p. 154) and he believes in plurality in the world of religions, rights, values and so on. On this basis, he envisages some rights and legal obligations in the New World for human beings, which he examines as human rights in opposition to duties. Soroush considers human beings, whether Muslim, Christian or otherwise, as having a series of rights and duties just because of being human; and he considers this idea as the key for understanding the philosophy of human rights in the new world. Soroush therefore regards religiousness in modern society as a human right and considers freedom in the new era to indicate exactly the same meaning (ibid, p.151).

The democratic religious government is another issue discussed by Soroush. In his discussion of government, religion and democracy influenced by Popper's scientific methodology and the gradual nature of growth in society, he presents his political and social theories. So he sees society and democracy in a state of constant experimentation, choice, and growth, which is evolved by religion (Soroush, 1997, p. 302). He spoke of the intersection between democracy and religion and then considers everyone's faith his private property (Soroush, 1997, p. 330). Faith plays an important role in Soroush's discussion of democratic government. In his view, people's faith is possible if they are free to choose. As a result, faith and freedom form the basis of democracy. As he sees the foundation of liberal democracy as pluralism, he sees the foundation of religious democracy as freedom of faith (ibid, P.330). Soroush strives to bridge the gap between democracy, the principles of religion and ethics. He therefore considers ethics the best support for democracy and the guarantor of its survival 
(ibid, P.330), and for Soroush the religions that support morality are the best guarantors of democracy (ibid, p. 329).

\subsection{Reza Davari, Defending Philosophy, Critique of Science and the West}

In the atmosphere of anti-modernity and anti-western sentiments, Davari considers the critical era seen in the present world as a crisis era of Western thought. The main issue in Davari's perception is the criticism of the wisdom of the modern age. Davari considers the rationality of the new age or subjectivity as the starting point of the new world, from which many practical developments and concepts of the new Western world derive. Influenced by Heidegger and Fardid, he considers the crisis of the new era to be the result of the rationality of the new era and considers this era to be an escape from humanism. He views many of the achievements of the west, including secularism, democracy, freedom, development, human rights, pluralism, science, modernity, politics, and reason, and so on as the result of this rationality and criticizes them. Under the influence of Heidegger, who considers metaphysical views and ontological distinguished and more authentic than scientific and positive view (Delacampagne, 2001, P.286), he defends philosophy and criticizes science. He defends humans and humanity against subjectivity. He considers a kind of history and a general nature for the West and considers it as the center of cruelty, rape and looting, the period of human domination, the end of the era of spirituality, and the age of human negation, and he rejects it. By defending of philosophy and applying Western anti-Enlightenment philosophical presuppositions, he discusses about the philosophy, science, society, politics, religion, freedom, development, human rights and more.

\subsubsection{Critique of Science and Defense of Philosophy}

With regards to the issue of science, Davari divides it into two parts, new and old. He, influenced by Heidegger, considers modern science to have a subjective presupposition that strives to conquer and change creatures and plan to change the world and the matter and uses methods. But he sees the old science as the science of understanding and possessing creatures and harmonizing with the world and nature (Davari, 2007 a, p. 204). He sees the difference between old science and modern science in methodology (ibid, p. 205). Davari considers that the spirit of conquest and subjugation that exists in new science is latent in the essence of new science and in the context of methodology, so he regards new knowledge as technological knowledge (ibid. 208). Davari considers new science as the science of conquest in nature and without a general meaning (Davari, 2010, p. 108).

Davari then criticizes the methodology and philosophy of science. He views methodology as the meaning of knowing the new science (ibid, p. 325). Davari considers researching the essence of a science as the work of philosophy and believes methodology is incapable of doing so (ibid, p. 325). In his view, the criterion and measure of being scientific in modern science is adherence to methodology. So, according to Davari since methodology was developed, it replaced philosophy and philosophy has been denied and it has fallen under science (ibid: 326). Davari believes that methodology is scientism and trying to prove the truth of the new science, and believes it serves the essence of technique, a technique that deprives human beings of freedom (ibid, p.327). He sees the dignity of this science in that it 
gives man the power to conquer the universe and man in a way that demands the essence of the new technique and considers it irrelevant to man's freedom from falsehood and his attachment to truth (ibid, p.330).

According to Davari, the emergence of new science is associated with the evolution of philosophy and philosophical thinking; the new philosophy is paving the way for a new world. The old science was related to the old philosophy, but the new science emerged whit the passage of the old philosophy, and by the disconnection with the new philosophy it became an ideology of ideologies. (ibid, p. 108).

Another issue raised by Davari involves philosophy. As to what philosophy is, he thinks it depends on what level the question is asked. According to Davari, Every philosopher defines philosophy in accordance with the basics of his thinking, and this is what the opponents of philosophy criticize (Davari, 1995, p. 61). Davari considers the founder of this criticism to be Descartes. In his definition of philosophy, following his antecedents, he sees it as moving from the first nature to the second nature, and considers philosophy and thought to be Irrelevant and incompatible with formal habits and opinions (ibid, p. 64). However, according to Davari, in the new era, philosophy has found another status. Francis Bacon found in philosophy the power to overcome the barriers of human sovereignty over nature, and Descartes knew true wisdom in making man the owner of nature. In general, according to Davari, in the new era of philosophy, it has become a guide to technology, science, culture and politics. Davari defines the meaning of philosophy as the love of knowledge (ibid, p. 11).

Influenced by Heidegger, Davari defends philosophy and considers it a kind of thinking. In his view, philosophy was able to defend itself as long as its existence was certain but when it changed into positivist religions, neo-positivist religions, pragmatism, and so on, there was no longer the need to defend philosophy, the thinking and defending it was abandoned, and philosophy reached a point where it replaced technological science. (Davari, 1984, p. 106, 107).

He rejects the critique of thought and philosophy by modern rationality and knows it as an empty rationality. He views opposition to philosophy in the West as antithetical to thinking. In criticizing positivist intellectuals, Davari believes that positivist philosophy has rules and principles that prove the one-dimensionality of the human beings. Therefore, they see nothing but peculiar reason and subsistence reason and certain science, and they do not place a high value on philosophy (Davari, 1995, p. 66). Davari argues that the positivist and neo-positivist philosophies are the sign of the wilting of philosophical thought, and considers the followers of these philosophies as those whose new science methodology is the absolute criterion of knowledge for them. He considers Carnap and Popper to be people of this type and believes that the measure for being scientific in their view is the ability to prove or nullification (Davari, 1987, p. 288). Davari considers that definition of philosophy which considers itself as the dominant philosophy in the west as pseudo-philosophy and rejects it in the name of science or logic and accuses its advocates of being impressed too much by science (Davari, 1987, p. 28). Ultimately, Davari considers defending philosophy as defending thought and believes that he defends philosophy so that at least it prevents the systematic dominance of 
our animal nature over our soul and being (ibid, p. 29).

\subsubsection{Criticizing the West}

Davari discusses the issue of west from two directions. First is the question of what west is and the second is the question of the essence and the nature of the west. Influenced by Heidegger and Fardid on the question of what the west is, he calls it a unity and a history. This history began when the Greeks paid attention to paideia, the making of man according to the example (Ideal human) that appeared in their minds (Davari, 2007 b, p. 1). According to Davari, paideia means culture and training and it is clear that the Greeks were not the discoverer and founder of education and culture; But a specific aspect that appeared to them from the universe and man, it led to the continuation of the historical process we now call Western history. This history has not always been in the same shape and it has had various forms, and in the recent period, it has changed into this form and gained the title of "new" and "modern" (ibid, p. 1).

Davari sees west as a fluid spirit; a fluid spirit that flows among the people, not all that exists in the Western world. In the modern age, he says, this fluid spirit is more fluid in technique, that we should not be considered equal to technology in its usual sense. The West is a history in the specific sense of the word or a culture, in other words the West is a world that has emerged and materialized in new civilization and life (ibid, P. 2). Davari sees the west as a precondition for the possibility of a new civilization, the condition for the emergence of new science and technology and the politics of countries and peoples called the West and the westerners, which means that the West is a unity or a whole. Davari regards west as a particular understanding of existence, an understanding that has appeared as nihilism. He views the West's perception of existence as technological understanding in which no practical order in politics and ethics can be extracted (ibid, P.12).

Then, Davari discusses the issue of the essence and nature of the west. Influenced by Heidegger and Fardid, he considers modern reason to be subjectivity, and he views the west on the orbit of subjectivity. Davari regards subjectivity as the status of an individual who claims to be independent and acts on the basis of reason. (Davari, 2010 a, P.74). Davari regards this reason as the product of Descartes' thinking and the new philosophy of Europe. According to Davari, by this rationality, there appeared a human being composed of wisdom and the actions of the self (ibid, P.76).

Davari regards the west as a way of thought and historical practice that began in Europe four hundred years ago and has expanded more or less everywhere in the world. According to Davari, west is something that is present in all the philosophies, ideologies, policies and literatures of the new European era; in one word, the west is the sunset of sacred truth, and the emergence of the man who holds himself to be the base of everything (ibid, p. 81).

\subsubsection{Theology of Davari}

Influenced by Heidegger, in defending tradition, Davari defends traditional jurisprudence and religion. Heidegger considers metaphysical and ontological view more authentic than the scientific view (Delacampagne, 2001, P.286). Influenced by this view, he criticizes 
considering traditional jurisprudence and religion based on the new scientific method; he argues that if religion is interpreted with the new scientific method and reason, religion becomes a set of virtues and information separate from the religious world and this is not a revival of religion. Davari considers the arguments of the critics of the traditional jurisprudence and the advocates of the dynamic jurisprudence as Political claim or statement (Davari, 1999, p. 299). He regards dynamic jurisprudence as a jurisprudence adapted to new reason, a reason that interprets religion and views metaphysical issues as meaningless; he asks the advocates of dynamic jurisprudence "how is it possible to change the religion based on the appearance of the western culture, and call it the revival of religion" (Davari, 2010, p. 207). In defense of traditional jurisprudence, he believes that "If we say that the present world needs religion; first of all, we need the principles of religion and their realization" (ibid, 2010, p. 228). Moreover, he believes that "interfere in the principles of religion and changing the sources of inferences is not necessary ... and since experts are responsible for identifying and determining the subject matter of judgments, it is not possible to incorporate new principles into the jurisprudence technique without the consideration of Jurisprudence experts and principles" (ibid, p. 299).

\subsubsection{The Political Philosophy of Davari}

The political philosophy of Davari includes the concepts of development, human rights, freedom, politics and philosophy, reason and politics. Influenced by Heidegger, Davari considers many of these concepts the result of modern world rationality and criticizes them. Concerning the concept of liberty, the Davari regards liberty as part of the human essence and different from Ebaheh (Not adhering to religious values) (ibid, p. 481). He sees the freedom of the new era as a form of liberalism, which is while in opposition to a form of old tyranny, but it is not in opposition to all types of tyranny (ibid, p. 482). He considers the new freedom to reach the western intellect and that is the freedom in which human beings find themselves in a position to take possession of everything and become the orbit of the universe. Ultimately, Davari considers true freedom as Reflection and striving and associates it with the development of truth and its realization (ibid, p. 492).

Regarding the relation between philosophy and politics, Davari believes these two have been related since the beginning of the history of philosophy, but he sees philosophy as placed on a higher level (Davari, 2004, p. 102). Davari considers the political system a derivation of the structure of the world, which is disrupted when the modern world came about. He considers this disconnection as caused by two factors: one is the establishment of a new relation between philosophy and politics in the new era and the confusion between the two and the other is the emergence of chaos in languages and the formation of grounds for misunderstanding. Davari sees philosophy as the basis for politics, but he considers the confusion between philosophy and politics and the dressing of philosophy for political purposes to be the work of people like Popper and Huntington. In the end, he believes that philosophy should not be a tool of politics and, if it does, become unfounded (ibid, p.102 and114). Davari sees the new politics and the new political rationality system as the indication of the rational system of the modern world (Davari, 2010 b, p. 124). He regards thought and culture as the support for political wisdom and he criticizes the fact that intellect 
and philosophy are influenced by politics.

Another issue raised by Davari involves human rights. In defense of human nature, he put forward the concept of human rights. Davari sees human rights as a principle before the socialization and outside time and history, which was developed in the western thought before the Declaration of Human Rights. However, he sees human rights, as a set of principles governing civil relations, as a concept belonging to the modern world (Davari, 2010 b, p. 222). While he considers the Universal Declaration of Human Rights based on natural rights, he regards it as a result of a huge transformation in the existence of human beings and calls it the modern constitution and the law of the modern world (ibid, p. 222 and 225).

In the end, it should be noted that Davari and Soroush somewhat revisited their ideas in their recent arguments, and they have become intellectually closer. Davari believes that we depend on social issues such as development, science, and technology and development is inevitable (Davari, 2005, p. 14). On the other hand, Soroush has somewhat distanced himself from his initial ideas. In this era, Soroush considered many of the concepts of the modern world as manifestations of the rationality of the modern era, which is the consequence of the era (Soroush, 2000 b, p. 5).

\section{Conclusions}

Among the groups claiming to provide solutions for the problems created in the new system of Iran, two groups represented by Abdolkarim Soroush and Reza Davari have been more significant than others. Influenced by Heidegger, Fardid, and continental philosophy, with religious and identity interests, Davari viewed the solution in the philosophy, opposition to science (modern science), anti-westernism, and taking a religious stance against the subjectivity of the modern era. However, Soroush saw the solution for the Iranian society in promoting science, selective defense of the west, and the defense of humanities. With his religious interests, and influenced by Popper's philosophy of science, analytical philosophy and liberalism, Soroush was looking to promote the compatibility between religion and modernity. Accordingly, both scholars have debated Discussions about science, philosophy, religion, politics, democracy, human rights, freedom, liberalism, and so on. The debates of the two started with difference and reached a climax. But, it seems that they have gotten closer in recent times and they have reached common points. That common point is that our problem is not the geographical aspect of the western world; we are facing an era of human history which has distinct characteristics. Davari considers the basic problems of the society as the inevitability of development, science, and technology; and Soroush believes that when we look at the dominating rational system and intellectual paradigm and measure the relations of the concepts, we will not make the mistake of imposing one discourse on another. 


\section{Acknowledgments}

This article has no sponsors and no one is sponsoring it. This article has only one original author and no other authors. Another author did not help the original author in writing this article. This article does not any author or opposing views. Finally, I would like to thank the reviewers of this article.

\section{References}

Bukhansky, I. (2000). Contemporary European philosophy, translated by Sharaf-aldin Khorasani. Tehran: cultural- scientific publications.

Bashiriyeh, H. (2000). Liberalism and conservatism. Tehran: ney Publishing.

Barkhordari, A. (2019). The Influence of Continental and Analytic Philosophy on the New Thinking of Iran. Advances in Social Sciences Research Journal, 6(3), 8-10. https://doi.org/10.14738/assrj.63.6171.

Barkhordari, A. (2020). Systematization and the Model of Political Management in Contemporary Iranian Thinker's Idea. Journal of Social Science Studies, 7(2), 58. https://doi.org/10.5296/jsss.v7i2.16937

Davari Ardakani, R. (1995). What is Philosophy? Tehran: Institute for Humanities and Cultural Studies publishing.

Davari Ardakani, R. (1987). Defense of Philosophy. Tehran: Research Office of Ministry of Culture and Islamic Guidance Publishing.

Davari Ardakani, R. (1984). Introduction From the history of our westernization. Tehran: Soroush Publishing.

Davari Ardakani, R. (2007 a). About the science. Tehran: Hermes publishing.

Davari Ardakani, R. (2007 b). About the West. Tehran: Hermes publishing.

Davari Ardakani, R. (2010 a). Philosophy in the Trap of Ideology. Tehran: international publishing.

Davari Ardakani, R. (2010 b). Politics, history and thought. Tehran: Saghi publishing.

Davari Ardakani, R. (1999). Culture, reason and freedom. Tehran: Saghi publishing.

Davari Ardakani, R. (2005 a). Treatise about Tradition and Modernity. Tehran: Saghi publication.

Davari Ardakani, R. (2004). Philosophy and contemporary human. Tehran: Institute for Research and Development of the Humanities publication.

Delacampagne, C. (2001). History of philosophy in the 20th century, translated by Bagher Parham. Tehran: Agah publishing. 
Hashemi, M. M. (2007). Modern religion thinkers. Tehran: Desert publishing.

Heidegger, M. (1998). Philosophy of technology, Translated by Shapuor Etemad. Tehran: Markaz publishing.

Jahanbegloo, R. (2005 a). Iran in South of Modernity. Tehran: Center Publishing.

Jahanbegloo, R. (2005 b). The fourth wave, translated by Mansour Goodarzi. Tehran: Ney Publishing.

Krichley, S. (2008). Continental philosophy, translated by Khashayar Deyhimi. Tehran: Mahi publishing.

Osborne, P. (1997). Modernity: Transation from past to the present. In The Blackwell com Panion to the cultural 8 cvitical theory.

Popper, K. (1984). Conjectures and refutations. Translated by Ahmad Arram. Tehran: Khwarizmi publishing.

Popper, K. R. (1975). Poverty of Historicism. Translated by Ahmad Arram. Tehran: Khwarizmi publishing.

Popper, K. R. (2001). Open Society and its Enemies, Translated by Ezatolah Fuoladvand. Tehran: Khwarizmi publishing.

Sedgwick, P. (2009). Descartes to Derrida, A review on European philosophy. Translated by Mohammad Reza Akhund Zadeh. Tehran: Ney publishing.

Soroush, A. K. (1977). What is science, what is Philosophy? Tehran: Serat publishing.

Soroush, A. K. (1981). Knowledge and Value. Tehran: Yaran publishing.

Soroush, A. K. (1993). Tafaroje Sonee: Speeches on ethics, industry and humanities. Tehran: Serat.

Soroush, A. K. (2002). Tradition and Secularism, dialogues between Soroush, Shabestari, Malekian and Kadivar, Tehran: Serat publishing.

Soroush, A. K. (2003). Theoretical Expansion of the Shari'ah. Tehran: Sarat Cultural Institute publishing.

Soroush, A. K. (1998). Straight lines (Serathaye mostaghim), Tehran: Serat Cultural Institute publishing.

Soroush, A. K. (2000 a). Expanding the prophetic experience. Tehran: Serat Cultural Institute publishing.

Soroush, A. K. (2000 b). Monarchy ritual and religiosity. Tehran: Serat Cultural Institute publishing.

Soroush, A. K. (2001). The Ethics of the Gods. Tehran: Tarhe no publishing.

Soroush, A. K. (1997). Toleration and management. Tehran: Serat publishing. 


\section{Macrothink

Soroush, A. K. (2000). Enlightenment, secrecy and religiosity. Tehran: Serat publishing.

\section{Copyright Disclaimer}

Copyright for this article is retained by the author(s), with first publication rights granted to the journal.

This is an open-access article distributed under the terms and conditions of the Creative Commons Attribution license (http://creativecommons.org/licenses/by/3.0/). 